Article

\title{
Advancing Urban Water Security in the Indus Basin, Pakistan-Priority Actions for Karachi and Lahore
}

\author{
Amy Syvrud ${ }^{1, *}$, Huw Pohlner ${ }^{1}$, Jehangir F. Punthakey ${ }^{2}$, Melita Grant ${ }^{3}\left(\mathbb{D}\right.$ and Trudy Green ${ }^{4}$ \\ 1 Aither Pty Ltd., Melbourne, VIC 3000, Australia; huw.pohlner@aither.com.au \\ 2 Ecoseal Developments Pty Ltd., P.O. Box 496, Roseville, NSW 2069, Australia; eco@ecoseal.com \\ 3 Institute for Sustainable Futures, University of Technology Sydney, Sydney, NSW 2007, Australia; \\ Melita.grant@uts.edu.au \\ 4 eWater Ltd., P.O. Box 328, Canberra, ACT 2615, Australia; trudy.green@ewater.org.au \\ * Correspondence: amy.syvrud@aither.com.au
}

Citation: Syvrud, A.; Pohlner, H.; Punthakey, J.F.; Grant, M.; Green, T. Advancing Urban Water Security in the Indus Basin, Pakistan-Priority Actions for Karachi and Lahore. Water 2021, 13, 3399. https:// doi.org/10.3390/w13233399

Academic Editors: Brian Richter and Christos Makropoulos

Received: 1 October 2021

Accepted: 18 November 2021

Published: 2 December 2021

Publisher's Note: MDPI stays neutral with regard to jurisdictional claims in published maps and institutional affiliations.

Copyright: (c) 2021 by the authors. Licensee MDPI, Basel, Switzerland. This article is an open access article distributed under the terms and conditions of the Creative Commons Attribution (CC BY) license (https:// creativecommons.org/licenses/by/ $4.0 /)$.

\begin{abstract}
Despite growing recognition of solutions to water scarcity challenges, decision-makers across the world continue to face barriers to effective implementation of water planning, governance and management. This is evident in the cases of Lahore and Karachi in the Indus Basin in Pakistan and illustrated through the experiences of the provincial government departments and utilities. Water scarcity and associated challenges are continuing to impose significant costs on these cities, which continue to grow as water availability further declines, demand increases, water quality deteriorates, and infrastructure degrades. A team of Australian water experts was commissioned by the Australian Water Partnership to diagnose urban water challenges and identify priority actions for improved water security, in collaboration with Pakistani partners. This paper presents the outcomes of that work. This includes a synthesis of the published literature and data on the geographical, climatic, and water scarcity contexts of both Karachi and Lahore. It then identifies responses to water insecurity that have been considered or implemented in the past and the barriers that have inhibited the effectiveness of these efforts. Finally, it presents actions within five priority action areas that Pakistani stakeholders have identified as being most practical and impactful for improving water security outcomes.
\end{abstract}

Keywords: urban water; water security; water policy; water management; Lahore; Pakistan; Karachi; Indus Basin; water governance

\section{Introduction}

The Indus River Basin extends over 1.12 million $\mathrm{km}^{2}$ and is a lifeline for more than 90 percent of Pakistan's population, including for the populations of Karachi and Lahore [1]. It is also one of the most vulnerable river basins in Asia and is a highly contested transboundary resource shared between Pakistan, India, China and Afghanistan (Figure 1) [1,2]. Pakistan is ranked as the fifth most vulnerable country to climate change, and communities, utilities and government bodies across Pakistan are already facing serious challenges associated with water scarcity and water quality deterioration [3].

Karachi's main water source is the Indus River, followed by supply from the Hub River [4]. Lahore, on the other hand, relies almost entirely on groundwater due to unreliable rainfall patterns and low capacity for surface water storage. The city of Lahore is underlain by unconsolidated alluvial deposits that have formed an unconfined aquifer more than $400 \mathrm{~m}$ thick [5]. The River Ravi, a tributary of the Indus River Basin, runs along the north and western outskirts of Lahore, contributing to aquifer recharge. However, in both cities, water supply is stressed, water quality is poor, and exponential population growth and climate impacts are only exacerbating these challenges (see Sections 3 and 4). 


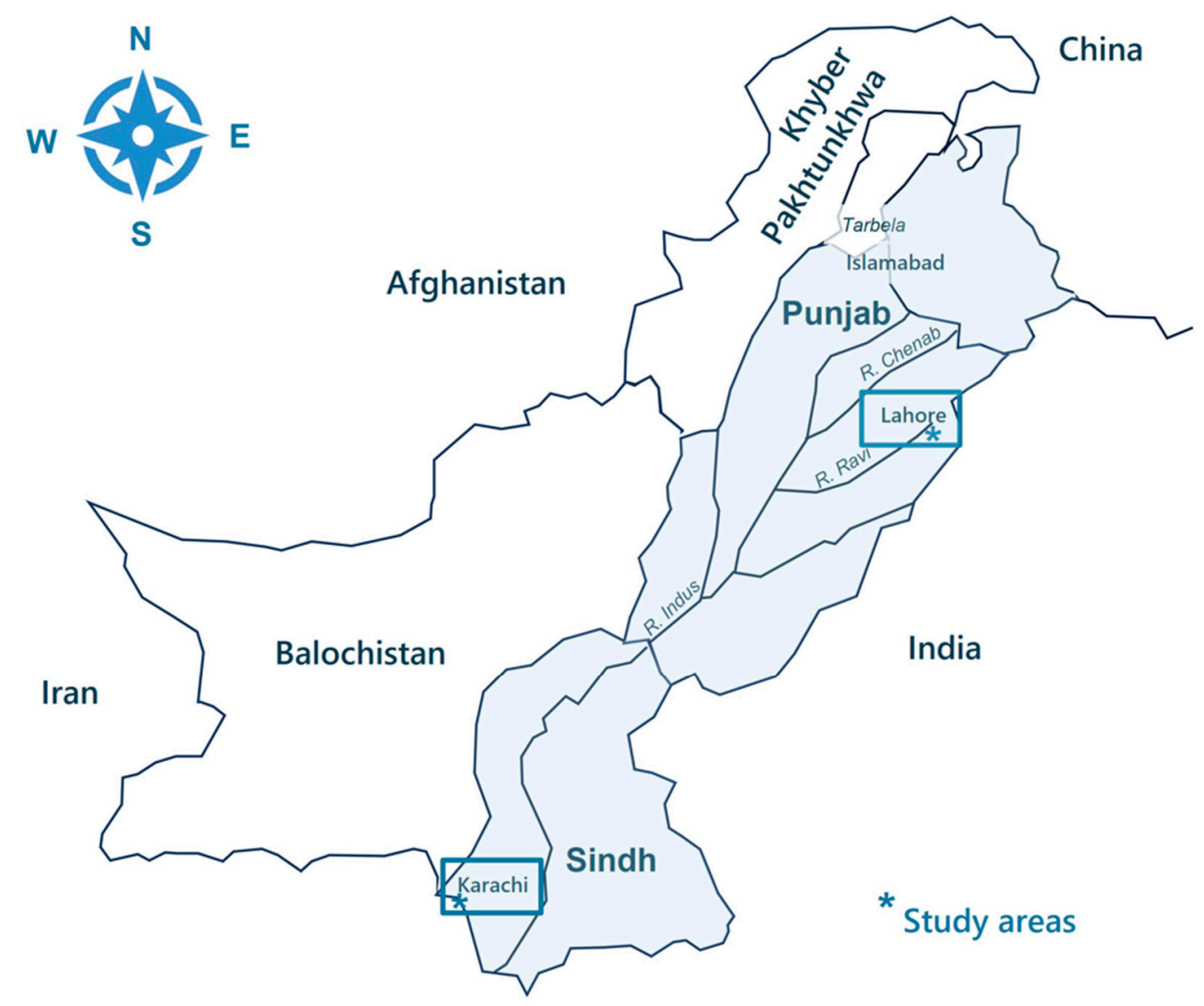

Figure 1. Locations of Karachi and Lahore within the Indus River Basin.

While significant efforts have been made to address water supply and demand challenges, including through policy development and infrastructure investment, there are barriers preventing the efficacy of these solutions. Capacity limitations as well as political hurdles have led to weaknesses in institutional coordination, in data collection and management, in policy and regulatory implementation, and accountability [6]. National and provincial government bodies have taken major strides to develop appropriate legislation and regulation, which is necessary for effective water management, but not sufficient to enable adequate water sector performance. Most solutions designed and facilitated by external partners such as development banks, have focused on master planning and infrastructure investment. These have often failed after the design phase, with little progress after years of planning, as resources become depleted and/or political barriers arise [7,8]. As a result, there is an urgent need to better coordinate actors and strategically direct investment to highest priority actions that hold the greatest potential for implementation success.

The methodology for undertaking this work is presented in Section 2. Findings and outcomes are presented in the remaining sections, with geographical and climatic contexts presented in Section 3, an overview of the evolution of water scarcity presented in Section 4, analysis of existing water security efforts presented in Section 5, and identified priority action areas for progressing towards water security presented in Section 6. A summary of the identified priority action areas, actions and anticipated benefits of action, is presented in the Conclusion.

\section{Methodology}

Pakistan (as represented by the Ministry of Water Resources) and Australia (as represented by the Department of Foreign Affairs and Trade) signed a five-year Memorandum of Understanding (MoU) in 2018 to support Pakistan's transition towards improved water resource management [9]. Pakistan's Ministry of Water Resources selected urban water 
as one of the priority areas for attention under the MoU. Given Australia's experience in managing scarce water resources and success in urban water reform, the Australian Water Partnership (AWP) commissioned a consortium of Australian Partners (namely, Aither, eWater Ltd., Ecoseal, Institute for Sustainable Futures and Water Futures) to prepare urban water diagnostics and urban water security roadmaps for the cities of Karachi and Lahore.

The Pakistan Water Diagnostic and Roadmaps Project commenced in February 2020. The first step was to prepare diagnostic reports for both Lahore and Karachi that identified and assessed urban water management challenges and opportunities for improvements. Findings in these reports were based on a comprehensive review of previous work and consultation with Pakistani partners. This information has informed Sections 3 and 4. Following the development of diagnostic reports, the project team undertook further engagement with Pakistani partners to inform a roadmap document for each city. The roadmap documents outlined priority action areas for improving water security in each city. Additionally, the team developed supplementary implementation plans for specific actions, including with preliminary cost estimates, timing suggestions, and stakeholder responsibilities. The priority action areas and actions identified through the project are presented in Section 6.

The project team intended to undertake three in-person missions to Pakistan to support this work. However, travel was not possible due to the COVID-19 pandemic. Despite the inability to travel, the project team engaged substantively with Pakistani stakeholders via virtual platforms, supported by a local Pakistani consultant. From September to December 2020, representatives from provincial government departments (Sindh and Punjab Planning and Developing Departments, Irrigation Departments and Punjab Housing and Urban Development, Public Health and Engineering Department), utilities in Lahore and Karachi (Lahore Water and Sanitation Agency (Lahore WASA) and the Karachi Water and Sewerage Board (KWSB)), donor banks (World Bank, Asian Development Bank), and non-governmental organizations and research institutes (International Water Management Institute, Institute of Water Resources Engineering and Management, WaterAid Pakistan) participated in virtual interviews and workshops. Some representatives also provided data and information via a Microsoft Excel tool that outlined questions for response, organized against a six-element framework for improved water management and use in response to water insecurity [10]. Further, project focal persons from Lahore WASA, KWSB, and the provincial Planning and Development Departments reviewed and provided feedback on all project outputs.

The objective of this project and its outputs is to assist government departments and utilities in Karachi and Lahore to pursue and effectively implement highest priority actions for improving urban water security.

\section{Geography and Climate of Karachi and Lahore}

\subsection{Geography and Population}

Karachi, the capital of Sindh province, is a coastal city located in the south of Pakistan. The city covers an area of $3780 \mathrm{~km}^{2}$ and borders the Lasbela District to the west and the Jamshoro District to the northwest. The southern border of Karachi is the coastline of the Arabian sea. Karachi is the largest and most densely populated city in Pakistan with a population just over 16 million people [11]. Between 1998 and 2020, the population of Karachi grew by 72 percent (Table 1) [11]. With an annual growth rate of approximately 5 percent, Karachi's population is expected to grow by an additional 7 million inhabitants by 2035 [11].

Lahore is situated in Pakistan's central east, neighboring the Indian states of Punjab and Himachal Pradesh. The city covers an area of $1772 \mathrm{~km}^{2}$ and is bounded by the north and west by the Sheikhupura District and by the Kasur District in the south. It is located on a flat alluvial plain on either side of the River Ravi, a tributary of the Indus [8]. Lahore is the country's second most populous city with a population of over 12 million people [6]. The city's population growth increased by 116 percent between 1998 (5.14 million) and 
2017 (11.12 million), and the population is projected to grow by an additional 51 percent by 2035 (19.12 million) (Table 1) [11].

Table 1. Population growth within Karachi and Lahore from 1998 [11].

\begin{tabular}{ccccc}
\hline City & Census 1998 (Million) & Census 2020 (Million) & Census 2035 (Million) & Percentage Increase (2020-2035) (\%) \\
\hline Karachi & 9.33 & 1.09 & 23.13 & 43.8 \\
\hline Lahore & 5.14 & 12.64 & 19.12 & 51.27 \\
\hline
\end{tabular}

\subsection{Climatic Context}

Lahore's climate is described as semi-arid, with long and hot summers and comparatively short and mild winters [12]. Maximum temperatures in the summer have been recorded exceeding $48{ }^{\circ} \mathrm{C}$, and heat wave events are common in May and June. The River Ravi nearly runs dry for most of the year, except during the rainy season. Southwest monsoons during June to September deliver most of Lahore's rainfall, with an average annual precipitation of $673 \mathrm{~mm}$.

In Karachi, coastal influences result in a relatively mild climate. Summer months can consist of high humidity, extreme heat and heatwave events, as well as tropical storms along the coastline [13]. Winter months are usually mild with temperatures rarely dropping below $0{ }^{\circ} \mathrm{C}$. The average annual rainfall for Karachi is $174.6 \mathrm{~mm}$ and is influenced by monsoonal rains during the summer months from July to September, which often cause widespread flooding [13].

\section{Evolution of Water Scarcity in Karachi and Lahore}

\subsection{Water Availability}

In Lahore, water supply for drinking, domestic, commercial, and industrial use relies entirely on groundwater. The utility Lahore Water and Sanitation Agency (Lahore WASA) provides most of the city's water services. Groundwater is abstracted through an estimated 597 tube wells installed across the Lahore Municipal Area, and numerous privately owned pumps are also in operation [14]. The number of wells, and therefore the amount of groundwater abstraction, has reduced the rate and volume of aquifer recharge, resulting in severely depleted resources across the region $[7,15]$. The River Ravi runs through Lahore, but it is increasingly dry, and does not contribute much to aquifer recharge. For the past 50 years, groundwater levels around Lahore have been dropping by 0.5 to $0.8 \mathrm{~m}$ per year (Figure 2) [7].

In Karachi, the Indus River supplies approximately 2.5 million cubic meters per day (MCM/day), which is about 85 percent of total water supplied to the city [16]. Surface water from the Hub River also contributes to Karachi's supply-total water available from the Indus and Hub Rivers totals approximately 2.95 MCM/day (Table 2) [16]. However, supply from the Hub River is heavily rainfall-dependent, and its contribution has varied considerably over the years [17]. An estimated 35 percent (1.05 MCM/day) of supplied water is lost during transmission due to illegal connections, evaporative losses, and leakage, thus decreasing water availability to $1.97 \mathrm{MCM}$ /day. Unlike Lahore, Karachi does not rely on groundwater as an additional supply source due to salinity. It receives a negligible supply from the Dumlottee well field, which provides $2.3 \mathrm{MCM} /$ year of water after the monsoon season, while remaining dry for the rest of the year [15]. 


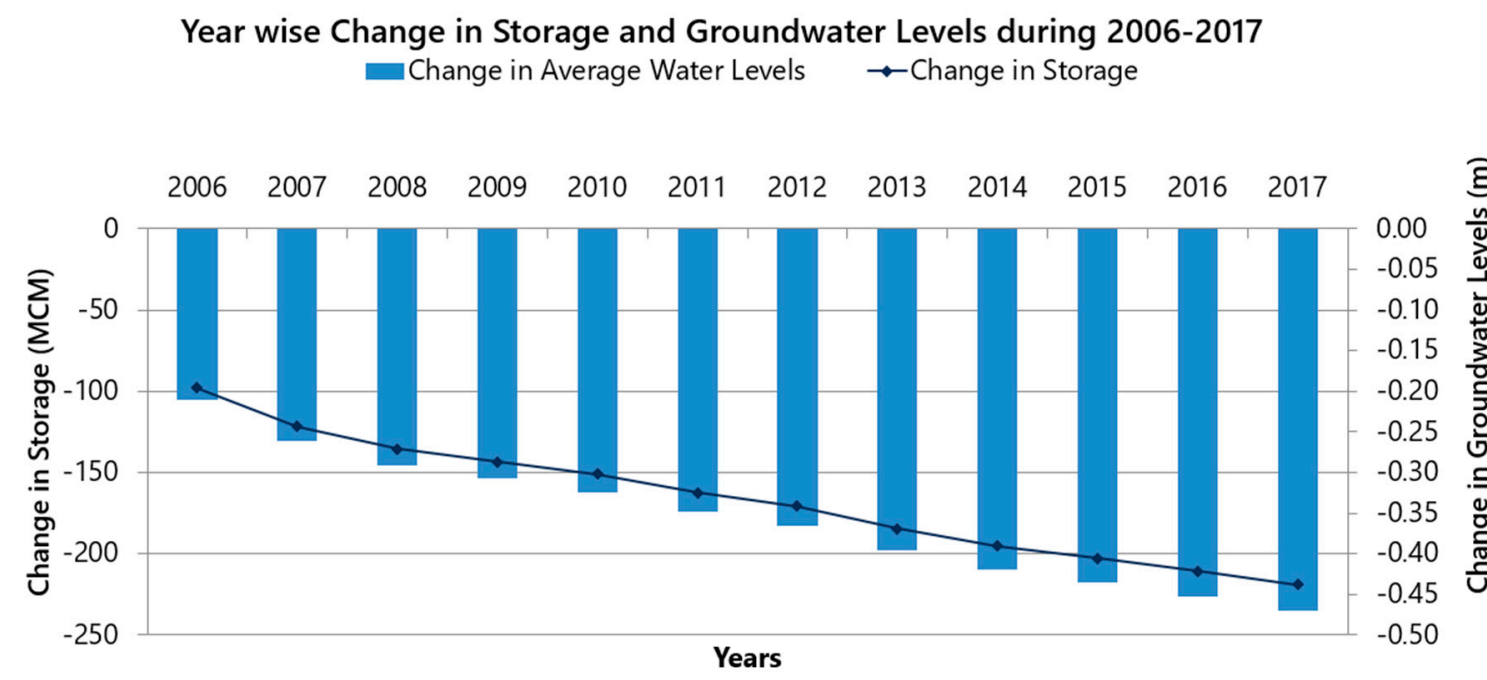

Figure 2. Annual change in Lahore water storage and groundwater levels [7].

Table 2. Main water sources of Karachi [16].

\begin{tabular}{cc}
\hline Water Source & MCM/Day \\
\hline Indus River & 2.5 \\
\hline Hub River & 0.45 \\
\hline Dumlottee well field & $0.025^{*}$ \\
\hline Tanker water & Unknown \\
\hline Small vendors / bottled water & Unknown \\
\hline During monsoon season only (considering a 90-day monsoon).
\end{tabular}

The utility Karachi Water and Sewerage Board (KWSB) is the main water service provider in Karachi. The KWSB serves approximately 30 percent of households, but water supply services are intermittent, with typical service quality ranging from 'two hours every two days to four hours per day at very low pressure' [6]. As a result, many households turn to alternative water providers and pay much higher costs. Tanker mafias allegedly control water valves in Karachi, making corruption and water theft a major challenge for infrastructure operation [18]. It has been estimated that 25 percent of households receive their water from tanker trucks, and 34 percent from small vendors or bottled water [18].

\subsection{Water Demand}

The combination of a rapidly increasing population, continued industrial expansion, and changing domestic water usage practices has resulted in a significant increase in water demand across the province of Punjab, and particularly within the city of Lahore. Domestic water use comprises most water demand in Lahore. Lahore WASA has estimated that daily per capita water demand increased by 67.7 percent between 1967 and 2018.

As a result of the COVID-19 pandemic, the World Bank has observed a further increase in water demand in urban areas in Pakistan, including in Lahore (personal communication, 27 September 2020). This is associated with increased water use for sanitation purposes. Even prior to the COVID-19 pandemic, it was projected that municipal water demand (particularly in Lahore WASA utility coverages areas) would continue to increase steadily in the future (Figure 3) [7]. 


\section{Projected Municipal Water Demand in Lahore District (MCM)}

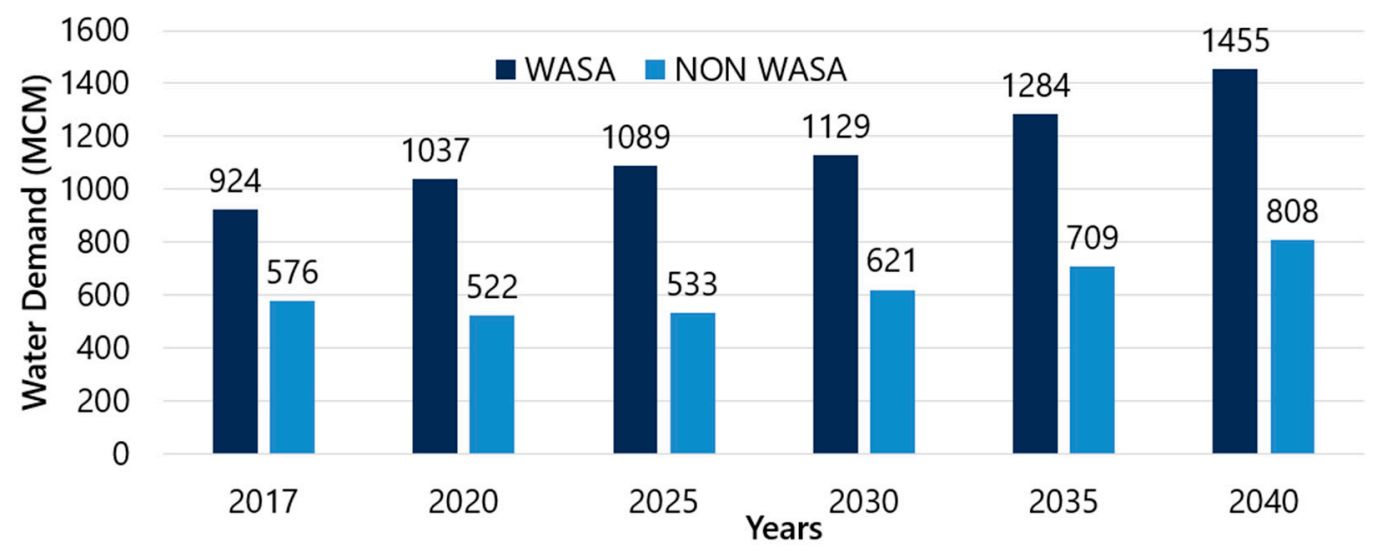

Figure 3. Annual change in Lahore municipal water demand [7].

The Karachi Water and Sewerage Board estimate that the total water demand to meet urban needs in Karachi is between 3.73 and $5.46 \mathrm{MCM} /$ day. The World Bank estimates that current demand is $5.5 \mathrm{MCM} /$ day [6]. It is projected that water demand will continue to increase steadily in the future due to a growing population and increasing wealth. A 50 percent increase in bulk water supply is projected to be required by 2047 [6]. Additionally, the use of groundwater has increased for many domestic and industrial purposes within the city, and this trend is likely to continue despite severe constraints on groundwater availability. These projections do not account for the increase in demand that has resulted from the COVID-19 pandemic. Similar to Lahore, an observed increase in demand has occurred in Karachi, associated with increased water use for sanitation purposes.

\subsection{Water Quality}

Inadequate solid waste management, uncontrolled wastewater discharge, and leakage of sewage have resulted in microbial contamination of drinking water supplies in both Lahore and Karachi.

In Lahore, groundwater quality is deteriorating due to wastewater discharge to the River Ravi. Lahore's 14 wastewater carrying drains contribute to more than 56 percent of the River Ravi's total pollutants. It is estimated that the River Ravi receives 540 MGD (2.38 MCM/day) of wastewater from Lahore WASA and other municipal service providers without any treatment $[7,19]$. Both municipal and industrial waste (untreated wastewater) is also directly discharged into the canal system by city residents and 271 industrial enterprises (including textiles, chemical, paper, poultry, dairy, tanneries, and pharmaceuticals). The River Ravi contributes over 80 percent of the recharge to the groundwater system, resulting in increased levels of pollution in the Lahore aquifer [20,21].

In Karachi, the most probable source of bacterial contamination is sewerage discharge, which typically flows in pipelines parallel to drinking and household water pipelines. Poor maintenance and breakages in these pipelines frequently lead to the mixing of water supply with the sewerage water [6]. Karachi produces around 2.16 MCM/day of wastewater daily, of which $1.91 \mathrm{MCM} /$ day remains untreated and severely contaminates surface and groundwater sources, as well as marine ecosystems. Groundwater quality in most areas of Karachi is of marginal quality, and the limited available sources of fresh groundwater are subject to contamination from sewage and salinity. As such, the quality of groundwater is very poor and often unfit for human consumption without prior treatment. These circumstances, combined with limited household-level water treatment (38 percent of households in Karachi do not treat their water), are contributing significantly to the spread of waterborne diseases [18]. 
The COVID-19 pandemic has also affected water quality in Lahore and Karachi. With an increase in hospital patients, hospital waste is becoming increasingly large in volume and containing increasing amounts of hazardous materials [22]. This not only poses additional risks to communities who depend on the waters receiving that waste and sewage, but also to the municipal workers in both cities.

\subsection{Supply-Demand Gap}

A daily average volumetric groundwater balance for the Lahore aquifer suggests abstraction exceeds recharge by around 10 percent (Table 3) [6]. This results in a net depletion of $0.67 \mathrm{MCM} /$ day (or $245 \mathrm{MCM}$ /year), leading to a fall in average groundwater levels of $0.55 \mathrm{~m}$ per year [23]. Other estimates suggest the gap is even greater than this. In 2011, groundwater levels were recorded at $38 \mathrm{~m}$ [24,25]. Groundwater levels by 2025 are projected to decline to $70 \mathrm{~m}$ [6]. By 2040, groundwater levels are estimated to decline below $100 \mathrm{~m}$, resulting in both declining water availability and quality [20].

Table 3. Current groundwater balance of the Lahore District [5].

\begin{tabular}{cc}
\hline Component & Recharge (MCM/Day) \\
\hline Groundwater Recharge & \\
\hline Irrigation distribution system and field application & 0.81 \\
\hline Rainfall & 0.38 \\
\hline Ravi River & 5.31 \\
\hline Total Recharge & $\mathbf{6 . 5 0}$ \\
\hline Groundwater Discharge & 3.79 \\
\hline Groundwater Abstraction for Domestic Water Supply & 0.92 \\
\hline Groundwater Abstraction for Industries & 0.76 \\
\hline Groundwater Abstraction for Commercial and \\
Institutions
\end{tabular}

Recent studies suggest that the water supplied to Karachi also fails to meet the water demand of the city. It is estimated that only 55 percent of water demand is currently being met [6]. According to KWSB, there is a current water supply shortfall of 0.7 to 2.43 MCM/day [23]. The World Bank estimates that the current water supply shortfall is higher, at $2.5 \mathrm{MCM} /$ day [6]. It has been estimated that $0.44 \mathrm{MCM} /$ day of additional water supply will be required every five years to bridge the gap between demand and supply [23].

According to the World Resources Institute's Aqueduct Water Risk Atlas, both Karachi and Lahore are currently experiencing 'extremely high' water stress (i.e., ratio of total water withdrawals to available renewable surface and groundwater supplies is over 80 percent). Further, both cities rank 'extremely high' for overall water risk, which accounts for physical quantity and quality risks, and regulatory and reputational risks [26]. Both cities are projected to continue experiencing extremely high water stress beyond 2040, with demand projected to grow for several decades and supply projected to decline due to climate change impacts and widespread pollution $[6,26]$.

\section{Analysis of Water Security Efforts in Karachi and Lahore}

\subsection{Policy and Regulatory Developments}

On paper, many of the policies required for a sound water management system in Karachi and Lahore have already been developed. The 18th Amendment to the Constitution of the Islamic Republic of Pakistan 1973 devolved water supply and sanitation 
responsibilities to the provincial governments, and national policies in the early 2000s, such as the National Sanitation Policy (2006) and National Drinking Water Policy (2009), provided general guidance to the provinces. The Urban Water and Sanitation Policy also intended to guide and support stakeholders in improving water and sanitation services by outlining how to prepare and notify a legal and regulatory framework, how to develop effective environmental conservation, and how to create effective health and hygiene education programs $[27,28]$.

However, there is no legal mandate for the regulatory oversight of urban water supply service provider performance [6]. Additionally, there is no regulation for the use of groundwater supplied from the Dumlottee wells in the case of Karachi, or an agency that has the responsibility to monitor and regulate private domestic wells, resulting in an uncontrolled increase in groundwater use.

Most importantly, for decades, institutions in Sindh and Punjab have been unable to adequately enforce the laws and policies that they have created [6], and this remains the case today. This is largely the result of a lack of capacity and resources within institutions to fulfil their roles and responsibilities. While environmental and health regulations exist to some extent, implementation of these is weak [20,29]. According to Ahmad, the Sindh Environmental Protection Agency has fewer than a dozen officers, who lack the capacity and resources to inspect industries being developed in Karachi [14]. These issues are compounded by political economy factors, such as class, gender, and environmental considerations. While new and improved development plans and laws continue to be created, such as the Punjab Water Act 2019, these are only adding to the list of responsibilities that institutions already cannot adequately fulfill.

\subsection{Data Collection and Management Efforts}

There are numerous initiatives and policies promoting improved water data collection in Lahore and Karachi, and throughout Pakistan more broadly. For instance, international donor funding is helping the Pakistan Water and Power Development Authority (WAPDA) to establish a modern water data management system. However, substantial work is required to capture legacy data, encourage wider adoption of this platform (or compatible platforms) across other federal and provincial agencies, establish processes and protocols for interagency data exchange, and facilitate online public data access.

Data collection roles and responsibilities exist across institutions, but fragmentation of these responsibilities is contributing to ineffective monitoring and poor coordination. While many data sets are being collected, they are often inconsistent in terms of results and units of measurement, and may also be duplicative, resulting in inefficient use of resources. There is also a general lack of reliability in existing datasets which is inhibiting effective water planning and management, contributing to high levels of non-revenue water (NRW) and unsustainable water use, and undermining the confidence of communities and industry.

\subsection{Master Planning and Infrastructure Investment}

To date, international assistance and investment for improving water security in Lahore and Karachi has largely been directed at infrastructure master planning and construction of new supply infrastructure and wastewater treatment plants. Examples of master planning exercises for Lahore include the Preparatory Study on Lahore Water Supply, Sewerage and Drainage Improvement Project, the Integrated Master Plan for Lahore 2021 (NESPAK), and the Master Plan Study for Water Supply, Sewerage System \& Drainage System for Lahore [7,8,15,30]. Similar examples for Karachi include the Karachi City Diagnostics, which resulted in the Karachi Transformation Strategy [21,31].

Multiple major water supply and/or sewerage related master planning exercises have been undertaken in the last 10 years, including feasibility studies and blueprints for construction of infrastructure. While multiple studies have supported the same recommendations (e.g., that Lahore WASA construct wastewater treatment plants at six locations with support from international finance institutions), recommended actions have not been 
completed. In the case of construction of treatment plants, locations were identified following both planning and design, but due to a lack of treatment technology identification, progress halted [7].

Additionally, both KWSB and Lahore WASA have undertaken their own significant planning efforts in collaboration with international donors and have identified where action is required. For instance, the World Bank, Asian Infrastructure Investment Bank, and Government of Pakistan are supporting KWSB with USD 1.6 billion over 12 years through the Karachi Water and Sewerage Services Improvement Project (KWSSIP) [32]. While a large number of investments have been identified under this project, KWSB has suggested that further assistance and investment are required to both prioritize and implement particular actions. Lahore WASA and other stakeholders in Punjab have similarly suggested that assistance is required for action implementation.

\section{Discussion-Priority Actions for Improved Water Security}

A holistic, inclusive and strategic approach to addressing water stress and insecurity in both cities is required. Resources are limited and investment must be directed to where it will yield the greatest benefits. Discussions with Pakistani stakeholders under the project funded by the Australian Government aimed to seek agreement on a subset of priority action areas that align with KWSB and Lahore WASA objectives. Selected action areas are cornerstone issues, as they intend to address multiple challenges. These are described below.

\subsection{Water Governance and Institutional Capacity}

There is a need to define and reassign institutional responsibilities associated with policymaking, regulation, information and data, and service delivery more clearly and strategically. Better coordination between federal, provincial, and local institutions, as well as improved utility capacity in financial management, operations and maintenance, will strengthen the sector's ability to respond to the current COVID-19 pandemic and to future challenges. It is possible to improve institutional capacity by focusing on the functions that each institution is responsible for and by assigning roles and responsibilities to institutions best placed to manage them.

There are significant benefits in taking action to improve upon current arrangements. This can contribute to more efficient management and delivery of services, leading to cost savings, better use of limited resources, greater reach of services and more equitable outcomes (including gender equality, disability, and social inclusion). To help achieve these benefits, the two identified actions of the highest priority include the delivery of international knowledge-sharing workshops to exchange lessons about political economy of reforms, and the design and implementation of a water utility 'twinning' program for KWSB and Lahore WASA.

\subsection{Data Collection and Management}

Effective data collection and use underpin the sustainable management of water resources, providing water managers with key information, such as how much water is available, how much is being used, and the risk of demand exceeding supply. Reliable, accurate and transparently collected data provides the basis for evidence-based decisionmaking, helping identify issues, prioritize investment and management actions, monitor implementation, and evaluate success.

An improved approach to data collection and management will provide greater certainty on actual water demand (across sectors) and support assessments of current and future water availability (surface, groundwater and alternative supplies). This will allow for better targeting of investment to address a range of challenges, including to reduce poverty and/or gender inequities (if data are disaggregated by sex, disability status and other factors related to marginalization). A strategy that identifies how to improve data on pollution sources and hotspots will allow for targeted investment to reduce contamination of water supplies from sewage, industrial and domestic pollution 
sources. Additionally, an approach to enhanced collection of business performance data can help both KWSB and Lahore WASA to prioritize service improvements, as there are currently gaps in performance data related to reliability of service provision, maintenance expenditure, project delivery and customer satisfaction. As such, an overarching data collection and management strategy should be developed as a priority.

\subsection{Utility Planning and Strategy Development}

Long-term planning and the development of a utility strategy can help utilities to effectively undertake strategic actions that deliver long-term outcomes and meet organizational goals. It can improve infrastructure and service resilience to climate change and natural disasters (e.g., flooding events), emergency situations (e.g., COVID-19), changing supply and demand, and other factors. To achieve this, the strategy should identify where assessment of options is required, and prioritise the implementation of these assessments (e.g., rigorous cost-benefit analyses of alternative water source options, disaster risk mitigation measures, and water quality improvement options). Properly undertaking these analyses will ensure that resources and efforts are directed to where they will yield the most value, increasing the efficiency of resources.

A utility strategy and/or infrastructure investment strategy can help enable KWSB and Lahore WASA to foster open, inclusive, transparent, and informed decision-making processes. It is important that women, people with disabilities and other minorities are involved in the decision-making and strategy development process to ensure equitable and sustainable outcomes, and to understand how options will impact on different parts of the community. Additionally, it is important that a strategy is accompanied by a performance assessment and reporting framework that can monitor, measure and report on the extent to which outcomes and objectives are being achieved. Furthermore, a customer relations management strategy could enhance customer satisfaction and ensure that customer objectives are effectively met.

\subsection{Financially Sustainable Provision of Water and Wastewater Services}

Ensuring that water and wastewater services are financially sustainable improves the ability to fulfil service delivery functions, including long-term infrastructure operation and maintenance, and the capacity to respond to emergency situations such as the COVID-19 pandemic. Improved infrastructure maintenance, along with improved collection of water fees (and better understanding of affordability factors, while managing informal private operators), can lead to dramatic reductions in non-revenue water and water leakage. This will also be improved by transparent sharing of costs based on willingness and ability to pay, with consideration of equity issues, and meeting the needs of marginalized people (including those living in informal settlements). Financially viable and sustainable water and sanitation services that can meet user needs will lead to greater customer satisfaction, higher rates of payment and uptake, and improved well-being of all citizens of Lahore and Karachi.

To enable financial sustainability of KWBS and WASA's services, an alternative tariff arrangement should be designed and implemented. This should be informed by gender equality, disability and social inclusion considerations, which can help ensure that user needs are met. However, it will be important that actions in the other areas are undertaken prior to tariff reform, as these will support the design and effective implementation of a new tariff regime.

\section{Conclusions}

Overall, the priority actions for improving water security in each city, as identified through engagement with Pakistani partners, include:

1. Water governance and institutional capacity

a. Knowledge-sharing workshops on political economy of reforms and institutional capacity-building (involving a range of actors in the capacity development process); 
b. Designing and implementing a long-term utility twinning program for KWSB and Lahore WASA.

2. Data collection and management

a. Develop a data collection and management strategy for KWSB and Lahore WASA (including data disaggregated by sex, class, disability status, and ethnicity).

3. Utility planning and strategy development

a. Design an inclusive organizational vision and strategy for KWSB, along with a framework for utility performance assessment and reporting;

b. Design a new infrastructure investment strategy for Lahore WASA (based on inclusive multi-criteria analysis processes with a broad range of actors);

c. Design strategy for improving customer relations management for KWSB and Lahore WASA, underpinned by an understanding of different customer segment's needs, water management behaviors, and interests.

4. Financially sustainable provision of water and wastewater services

a. Determine and design a preferred tariff arrangement, and develop an equitable and sustainable tariff model and implementation plan.

It is anticipated that effective delivery of the proposed actions will provide the following overall benefits for Karachi and Lahore:

- Strengthened capacity of and coordination between federal, provincial, and local institutions, including improved utility capacity to successfully respond to the COVID19 pandemic and to future shocks;

- Minimized uncertainty in datasets and the ability to direct data collection efforts to appropriately influence management and investment decisions;

- Improved ability of utility leaders to effectively plan and undertake strategic actions and make informed investment decisions to deliver long-term outcomes and meet organizational goals;

- Enhanced inclusivity and operational sustainability of water management systems in line with the Sustainable Development Goals;

- Improved financial capacity of the utilities to fulfil service delivery functions and achieve sustainable and resilient water and sanitation services, with greater customer satisfaction and improved wellbeing of all citizens of Karachi and Lahore.

Author Contributions: Investigation, A.S., H.P., J.F.P., M.G., T.G.; writing-original draft, A.S.; writing-review and editing, A.S., H.P., J.F.P., M.G. and T.G.; supervision, H.P.; project administration, A.S. All authors have read and agreed to the published version of the manuscript.

Funding: This research was funded by the Australian Government through the Australian Water Partnership.

Institutional Review Board Statement: This article is based on work completed as part of a consulting assignment. Interactions with interviewees and workshop participants occurred under the framework of a bilateral MoU between national governments and were conducted consistent with policies and procedures established by the funding entity, the Australian Water Partnership.

Informed Consent Statement: The study was conducted according to policies and procedures established by the funding entity, the Australian Water Partnership. Individual participants cannot be identified from this study. During the study, there was no physical contact with participants, no participants were recruited from vulnerable groups, and there was no risk of discomfort or psychological distress to participants or their families.

Data Availability Statement: Not applicable.

Acknowledgments: The work program was supported by the Australian Water Partnership, an international cooperation initiative helping developing countries in the Indo-Pacific region, and beyond, work towards the sustainable management of their water resources. The AWP is funded by the Australian Government through the Australian Department of Foreign Affairs and Trade and 
managed by eWater Limited. Other Australian Partners contributed to this work program, including eWater Ltd., WaterFutures, The University of Technology Sydney, and Ecoseal Developments Pty Ltd. The team was heavily supported by a local consultant in Pakistan, Arif Pervaiz, who was critical to project delivery. We also acknowledge the Aither team members who contributed to this work including Will Fargher and Rachel Horwood. Finally, we acknowledge the participation of Pakistani partners which informed this work, including the Australian High Commission Islamabad, the Pakistan Ministry of Water Resources, the Lahore Water and Sanitation Agency and the Karachi Water and Sewerage Board, among others.

Conflicts of Interest: The authors declare no conflict of interest.

\section{References}

1. Nawaz, R.; Dehlavi, A.; Bajwa, N. Indus River Basin Wetlands. In The Wetland Book; Finlayson, C., Milton, G., Prentice, R., Davidson, N., Eds.; Springer: Dordrecht, The Netherlands, 2018. [CrossRef]

2. World Bank. South Asia Water Initiative (SAWI). 2021. Available online: https://www.worldbank.org/en/programs/sawi\#2 (accessed on 4 February 2021).

3. Eckstein, D.; Künzel, V.; Schäfer, L.; Winges, M. Global Climate Risk Index 2020. Germanwatch e.V, Briefing Paper, 44 p. 2019. Available online: https:/ / germanwatch.org/sites/germanwatch.org/files/20-2-01e\%20Global\%20Climate\%20Risk\%20Index\%20 2020_10.pdf (accessed on 5 May 2020).

4. Pappas, G. Pakistan and Water: New Pressures on Global Security and Human Health. Am. J. Public Health 2011, 101, 786-788. [CrossRef] [PubMed]

5. Mahmood, K.; Khan, R.M.; Ashfaq, M.; Ahsan, H. Assessment of the Intrinsic Vulnerability to Groundwater Contamination in Lahore, Pakistan. Pak. J. Sci. Ind. Res. Ser. A Phys. Sci. 2015, 58, 8-16. Available online: https://www.researchgate.net/publication/ 280876117_Assessment_of_the_Intrinsic_Vulnerability_to_Groundwater_Contamination_in_Lahore_Pakistan (accessed on 6 June 2020).

6. Young, W.J.; Anwar, A.; Bhatti, T.; Borgomeo, E.; Davies, S.; Garthwaite III, W.R.; Gilmont, E.M.; Leb, C.; Lytton, L.; Makin, L.; et al. Pakistan: Getting More from Water. 2019. Available online: http://documents.worldbank.org/curated/en/25119154827564 5649/pdf/133964-WP-PUBLIC-ADD-SERIES-22-1-2019-18-56-25-W.pdf (accessed on 6 March 2020).

7. Mott MacDonald. Master Plan for Water Supply, Sewerage and Drainage System for Lahore. Volume I: Water Supply; Mott MacDonald: Islamabad, Pakistan, 2019.

8. Mott MacDonald. Master Plan for Water Supply, Sewerage and Drainage System for Lahore. Volume II: Water Sewerage and Drainage Systems; Mott MacDonald: Islamabad, Pakistan, 2019.

9. Diplomatic News Agency. Pakistan, Australia Sign MoU on Integrated Water Resources Management. DNA News. 2019. Available online: https: / / dnanews.com.pk/pakistan-australia-sign-mou-on-integrated-water-resources-management/ (accessed on 7 May 2020).

10. Aither. WaterGuide: Setting a Path to Improved Water Management and Use under Scarcity, 2nd ed.; The Australian Water Partnership: Canberra, Australia, 2018. Available online: https:/ / waterpartnership.org.au/wp-content/uploads/2018/03/18131-AWP-WaterGuide-Version-2.pdf (accessed on 18 February 2020).

11. World Population Review (WPR) Lahore. Lahore Population. 2020. Available online: https://worldpopulationreview.com/ world-cities/lahore-population/ (accessed on 8 January 2021).

12. Rasheed, M. Effects of Orientation and Glazing Material on Heat Gain in Semi-Arid Climate of Lahore; University of Management and Technology: Lahore, Pakistan, 2016. Available online: https://www.researchgate.net/publication/317660161_Effects_of_ Orientation_and_Glazing_material_on_Heat_Gain_in_Semi_Arid_Climate_of_Lahore (accessed on 5 May 2020).

13. World Bank. World Development Report-Conflict, Security, and Development. 2011. Available online: https://siteresources. worldbank.org/INTWDRS/Resources/WDR2011_Full_Text.pdf (accessed on 9 April 2020).

14. Ahmad, M.D.; Stewart, J.; Peña-Arancibia, J.; Kirby, M. Punjab Water Outlook: Impacts of Climate Change and Dam Sedimentation on Water for Irrigated Agriculture. Australian Commonwealth Scientific and Industrial Research Organisation (CSIRO). 2020. Available online: https://www.researchgate.net/publication/339200168_Punjab_water_outlook_Impacts_of_climate_change_ and_dam_sedimentation_on_water_for_irrigated_agriculture (accessed on 9 January 2021).

15. Japan International Cooperation Agency (JICA). The Study on Water Supply and Sewerage System in Karachi in the Islamic Republic of Pakistan. Final Report. 2010. Available online: http:/ /labs1.tribune.com.pk/aqua-final/kwsb-master-plan-jica.pdf (accessed on 10 July 2020).

16. Irfan, M.; Kazmi, S.J.K.; Arsalan, M.H. Sustainable harnessing of the surface water resources for Karachi: A geographic review. Arab. J. Geosciences. 2018, 11, 1-11. Available online: https://doi.org/10.1007/s12517-017-3365-6 (accessed on 12 June 2020). [CrossRef]

17. Hasan, A. Karachi Master Plan 2020. 2007. Available online: http:/ / arifhasan.org/karachi/karachi-master-plan-2020 (accessed on 10 January 2021). 
18. Mitlin, D.; Beard, V.A.; Satterthwaite, D.; Du, J. Unaffordable and Undrinkable: Rethinking Urban Water Access in the Global South. Towards a more Equal City. World Resources Institute. 2019. Available online: https://wrirosscities.org/research/ publication/unaffordable-and-undrinkable-rethinking-urban-water-access-global-south (accessed on 8 July 2020).

19. Lahore WASA. General Presentation of WASA. 2018. Available online: https:/ / prezi.com/p/kokfshbgeko3/general-presentationof-wasa-lda/?frame=ea2cb80a6d1c21b895cb7d9fca90a3a9cce89a7d (accessed on 12 March 2021).

20. Qureshi, A.S.; Sayed, A.H. Situation Analysis of Water Resources of Lahore: WWF-P Hosts Official Launch Ceremony of Report, Establishing a Case for Water Stewardship; WWF: Lahore, Pakistan, 2014. Available online: http:/ /67.222.34.53/wsp/pdf/SAWRLSummary. pdf (accessed on 2 August 2020).

21. World Bank. Lahore Water and Wastewater Management Project, 2018. In Project Summary Information (PSI); World Bank: Washington, DC, USA, 2018. Available online: https://www.aiib.org/en/projects/proposed/2018/_download/lahore/PSILahore-Water-and-Wastewater-Concept-Stage-4-May-2018.pdf (accessed on 12 July 2020).

22. Saqib Khalid, I. Managing Risks to Water and Sanitation Amid COVID-19. Policy Options for Pakistan; Sustainable Development Policy Institute: Islamabad, Pakistan, 2020.

23. Karachi Water and Sewerage Board (KWSB). 2020. Available online: http://www.kwsb.gos.pk/View.aspx?Page=25 (accessed on 14 May 2021).

24. Mahmood, Z.; Liepach, W. A productive and water-secure Pakistan. In The Report of the Water Sector Task Force of the Friends of Democratic Pakistan; Ministry of Water Resources: Islamabad, Pakistan, 2012. Available online: http://metameta.nl/wp-content/ uploads/2013/11/FoDP-WSTF-Report-Final-09-29-12.pdf (accessed on 12 June 2020).

25. Kanwal, S.; Farooq Gabriel, H.; Mahmood, K.; Roshaan Ali, S. Lahore's Groundwater Depletion-A Review of the Aquifer Susceptibility to Degradation and its Consequences. Technol. J. Univ. Eng. Technol. (UET) Taxila Pak. 2015, 20, 26-38.

26. World Resources Institute (WRI). Aqueduct Water Risk Atlas. 2019. Available online: https://www.wri.org/applications/ aqueduct/water-risk-atlas/ (accessed on 19 July 2020).

27. International Union for Conservation of Nature. Water Policy \& Institutions in Pakistan. Policy Briefings. 2014. Available online: https: / / waterinfo.net.pk/sites/default/files/knowledge/PWP\%20Policy $\% 20$ Brief $\% 20 I I \% 20-\% 20$ Water $\% 20$ Policy $\% 20$ and\%20Institutions\%20in\%20Pakistan.pdf (accessed on 3 June 2020).

28. Cooper, R. Water management/governance systems in Pakistan. In K4D Helpdesk Report; Institute of Development Studies: Brighton, UK, 2018. Available online: https:/ / assets.publishing.service.gov.uk/media/5c6c293140f0b647b35c4393/503_Water_ Governance_Systems_Pakistan.pdf (accessed on 5 May 2020).

29. Hashmi, I.; Qaiser, S.; Asma, S.; Khan, T.A.; Abbas, S. Assessing Microbiological Safety of Drinking Water: A Case Study of Islamabad, Pakistan. In Proceedings of the Pakistan Engineering Congress, Islamabad, Pakistan, 30 April 2011. Available online: https:/ / pecongress.org.pk/images/upload/books / Assessing\%20Microbiological\%20Safety \%20on\%20Drinking\%20 Water\%20A\%20Case\%20St.pdf (accessed on 12 January 2021).

30. NESPAK. Groundwater Resources Evaluation and Study of Aquifer under Lahore. Supplementary Report; National Engineering Services Pakistan (PvT) (NESPAK) Ltd., and Binnie \& Partners Consulting Engineers: London, UK, 1993.

31. Ashir, Z.; Khalid, D. Think Tank on the Rational Use of Water. In Urban Water Management—A Transformation Strategy for KWSB; Hissar Foundation: Karachi, Pakistan, 2019. Available online: http://hisaar.org/hf/wp-content/uploads/2019/04/UrbanWater-Management-HF-Think-Tank-April-2019.pdf (accessed on 13 January 2021).

32. World Bank. Combined Project Information Documents/Integrated Safeguards Datasheet (PID/ISDS). Karachi Water and Sewerage Services Improvement Project. 2019. Available online: http://documents.worldbank.org/curated/en/96902155 8415389470 / pdf / Project-Information-Document-Integrated-Safeguards-Data-Sheet-Karachi-Water-and-Sewerage-ServicesImprovement-Project-KWSSIP-P164704.pdf (accessed on 6 October 2020). 